\title{
The Participation of Rice Farmers In Capacity Building Programmes of Agricultural Development Programme in Kwara State, Nigeria.
}

\author{
${ }^{1}$ Obaniyi.K.S., ${ }^{1}$ Fabiyi,E,F., ${ }^{1}$ Adewole,M,A., ${ }^{2}$ Iyilade,A.O., and ${ }^{2}$ Onikoyi, M.P. \\ ${ }^{1}$ Department of Agricultural Economics and Extension, Landmark University Omu-Aran, P.M.B1001,KM 4 \\ Ipetu Road, Kwara State, Nigeria \\ ${ }^{2}$ Agricultural and Rural Management Training Institute (ARMTI)
}

\begin{abstract}
This study was carried-out to examine the participation of rice farmers in capacity building training programmes organized by Agricultural Development Programme in collaboration with other bodies such as Olam, USAID and First Bank in Kwara State, Nigeria .

A sample of 180 contract farmers from two Local Government Areas of Kwara State who participated in the training were randomly selected and interviewed. Descriptive statistics and inferential statistics were employed in data analyses which include the use of frequency count, mean, pie-chart, bar chart, percentages and regression analysis.

The findings revealed the level of participation of rice farmers in the two major rice producing Local Government Areas (Edu and Patigi). The results revealed that the farmers' participation level was high in Patigi Local Government Area with participation mean of 6.189, and low in Edu LGA with participation mean of 3.267.

Regression analysis showed that there were positive relationships between participation levels of farmers in capacity building programmes and age, educational levels, household size, years of experience, secondary occupation, farm size and land ownership. It is recommended that the venue of the training should be decentralized for the farmers to have access to the place of training.
\end{abstract}

Keywords: Capacity building, levels, participation, training,

\section{Introduction}

Capacity building is the process of acquiring skills and training in any field of life. ( Ajayi [1]) defined training as the acquisition of the best way of utilizing knowledge and skill while (Owona et al. [2]) defined training need as skill, knowledge and attitude an individual requires in order to overcome problem as well as to avoid creating problem situation. For this study, capacity building is seen as the process of acquiring technical knowledge and training in the area of rice production, processing and marketing.

Rice is a typical cereal crop that has moved from ceremonial to a staple food in Nigerian homes. Statistics from the European Association of Agricultural Economics, EAAE indicates that Nigeria's by far the largest rice importer in West Africa, with an average yearly import of over 2 million metric tons since the year 2000 (USAID Markets, [3]). Total consumption stands at 4.4 million metric tons of milled rice while annual consumption per capita stands at $29 \mathrm{~kg}$ and this has continued to rise at $11 \%$ per annum, induced by income growth. However, Nigeria produces only about 2.8 million metric tons with a deficit of about 2 million tons, excluding the huge quantity smuggled through the porous borders. Presently, Nigeria's rice sub-sector is dominated by weak and inefficient producer-market linkages due to lack of production, technical know- how, poor infrastructure including lack of improved processing facilities, low rice productivity, poor post -harvest handling and storage, expensive and poor access to inputs (high quality seed, fertilizer, and crop protection products (USAID Markets, [3],)

According to (Ibrahim [5]) Nigeria has the capacity to be a major exporter of rice in a very short time, but this is only possible if we produce a product that competes with those coming from any other part of the world. Meanwhile, (Fashola et al. [6]), reported that training farmers for development is one of the numerous activities that need to be carried out to sustain production of food and to enhance self-sufficiency in food production in the developing world. He also added that training is mostly directed at improving the ability of individuals to make their vocation more effectively and efficiently and that it involves acquiring information and developing abilities or attitudes, which will result in greater competence in the performance of a work. Farmers have produced crops since ages by inheriting the production technologies from their ancestors and these olden day technologies cannot meet up with the demand of the present. Research scientists are also endeavouring to develop new technologies that will increase the production and productivity of various crops at the farm level. 
However, it has been observed that the recent production technology developed by the research has not been fully harnessed because the majority of farmers lack the capacity to utilize them.

The contributions of training to agricultural development has been highlighted as thus: providing farmers with the basic skills; improving rationality and increasing inquisitiveness and thereby improving receptivity to new ideas and strengthening the willingness to economize and facilitate the adoption of new techniques. (Mengistu [7])

Furthermore, on the importance of training and active participation for success in any rural development endeavour, (Bari, [8]) reported that for an effective rural development process to take place, participation of rural people in the development process is essential. In other word, it is the involvement of rice farmers in the capacity building programme that is designed for them that will determine their output level if the acquired skill is put to use. (Isiaku [9]) asserted that it is training that will help farmers to boost rice production with a view to attaining the objective of Government to stop rice importation by 2016.

This is one of the reasons while the Kwara Agricultural Development Programmes in collaboration with other bodies such as Olam, USAID and First Bank in Kwara State, Nigeria organized capacity building programme for rice farmers that covers rice agronomy, management, processing (which is value addition) and marketing. The objectives of the programmes include: to improve the capacity of farmers and build up confidence in them ; to increase yield or output of the farmers; to improve the welfare of the farmers through high income and to make farmers to see farming as a business in which they can make profit. This is line with the objective of Agricultural Transformation Agenda of Federal Republic of Nigeria.

It is against this backdrop that this study sets out to evaluate the participation of rice farmers in capacity building programme of Agricultural Development Programme in Kwara state, Nigeria.

Therefore, the main objective of this study is to assess the participation of rice farmers in capacity building programme of Agricultural Development Programme in Kwara State, Nigeria.

The specific objectives include:

1. To identify the capacity building programmes of Agricultural Development Programmes used in the study.

2 To examine the participation levels of rice farmers in the capacity building programmes

3 To compare the participation of rice farmers in the two LGAs

1.1. Hypothesis

There is no significant relationship between some selected personal characteristics of rice farmers and their participation level in the two LGAs

\subsection{Study Area}

\section{Methodology}

Kwara State is situated between Latitudes $11^{\circ} 2^{\prime}$ and $11^{\circ} 45^{\prime} \mathrm{E}$ and Longitude $2^{\circ} 45^{\prime}$ and $6^{\circ} 40^{\prime} \mathrm{N}$. Kwara occupies a vantage position on the map of Nigeria. It shares the same borders with Niger State in the north and the south-west states of Osun, Oyo. Ekiti and the Republic of Benin The study was carried out in Patigi Local Government Area (consisting of three districts including Patigi, Lade and Kpada) and Edu local government are (consisting of three district Lafiagi, Tsaragi and Rogun.

Patigi LGA is geographically located between Longitude $4^{\circ} 54^{\prime}$ and $5^{\circ} 36^{\prime}$ and latitude $8^{\circ} 36^{\prime}$ and $9^{\circ} 14^{\prime}$ with an area of $1168 \mathrm{~km}^{2}$ The location shares common boundaries with Niger State, Kogi State as well as Edu and Irepodun Local Government Areas. It has a total land area of about $2924.62 \mathrm{sq} . \mathrm{km}$, which is about $5 \%$ of the total land area of the state - Kwara State (www.kwarastate.com). According to Kwara State Agricultural Development Project, (KWADP, [10]), approximately $25 \%$ of the land area of the Local Government is used for farming activities.

The information from the (Meteorological Office [11]) Ilorin shows that the study area falls within humid climate with two distinct seasons (the wet and dry seasons). The wet season lasts between April and October during which there is rain and dry season is between November and March. The rainfall ranges between $50.8 \mathrm{~mm}$ during the driest months to $2413.3 \mathrm{~mm}$ in the wettest months. The minimum average temperature throughout the state ranges between $21.10^{\mathrm{c}}$ and $25.00^{\mathrm{c}}$ while, maximum average temperature ranges from $30^{\mathrm{c}}$ to $35^{\mathrm{c}}$.

The soil is red laterite of tropical area formed under seasonal rainfall climatic region. Soil aggregation is poor, with tendency to compact under wet condition. Surface texture is sandy loam. Clay is predominantly kaolite. Soil is about $30-40 \%$ clay especially with depth. The climax vegetation was tropical deciduous forest but the influence of man, especially farming activities has turned it into dry woodland savanna, which is characterized with scattered trees and tall grasses.

The study area was chosen because agriculture is the bedrock of its economy and also characterized with various forms of ecological zones that give rise to different types of crop. The typical cropping systems in the study area 
are, Rice - based system, Sugar Cane-based system, Ground Nut -based systems, Millet-based system and Melon cultivation in areas located along river Niger, the major river in the study area.

The total estimated population of Patigi Local Government Area according to (National Population Commision, [12]) is about 45,494 (22,712 males, 22,782 females) of which farmers account for about $70 \%$. Agricultural production is largely peasant and small-scale relying heavily on the use of manual labour equipped with crude implements, while fertilizers, mechanical implement, improved seeds and agrochemicals are also used to some extent (KWADP, 2007).

\subsection{Data collection and sampling technique}

All participating farmers in the project constitute the population of study, they were about 3,000, out of which 90 respondents were randomly selected from Patigi LGA ( 30 respondents from each district of the three district) and remaining 90 respondents randomly selected from Edu LGA ( 30 respondents from each district of the three district), given a total sample size of 180. The data collected were analyzed using the Statistical Package for Social Sciences (SPSS, version 15),the descriptive statistic and inferential statistics such as frequency counts, percentages, means and regression analysis were used to describe the variables and to examine relationship between some personal characteristics of the rice farmers and their participation in programme . Also diagrammatic representation of pie chart and bar-chart was used to compare the result.

\section{Results and Discussion}

\subsection{The level of participation of respondents in Patigi and Edu local government}

Table 1: Distribution of respondents according to their participation level in the programme

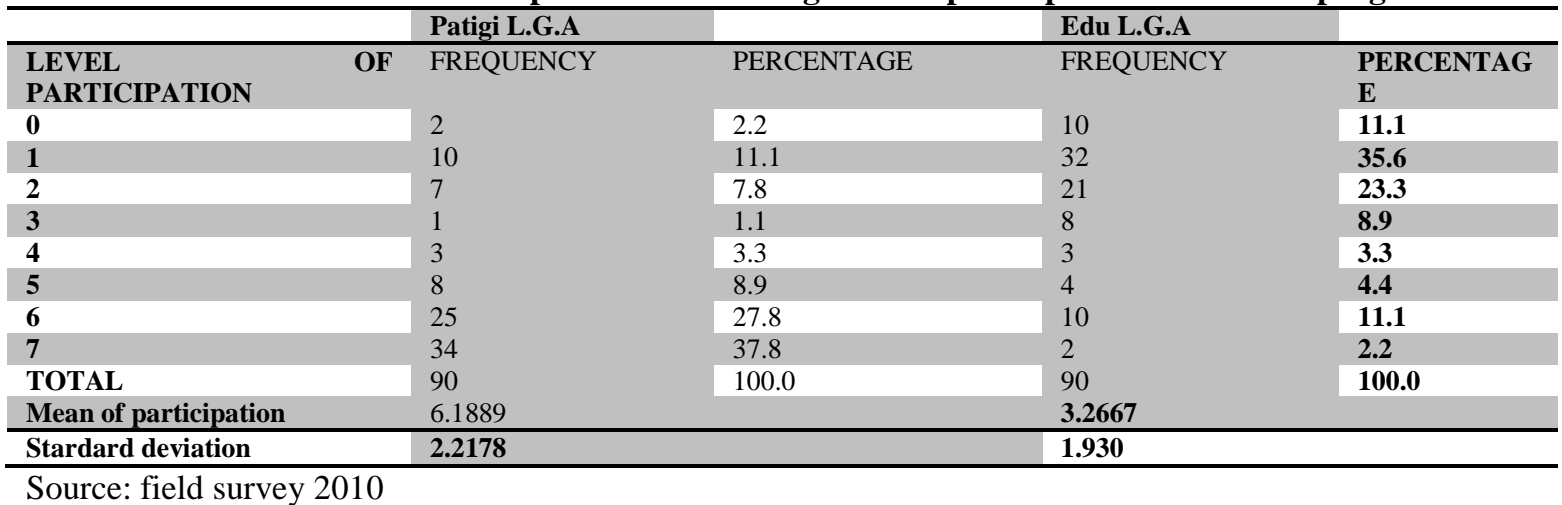

The training covered viz: Training of the Trainer ( TOT), Green Field Day, Brown Field Day, Contract Spraying Training, Group Dynamic Capacity Training (GDCT), Leadership training and Farm demonstration

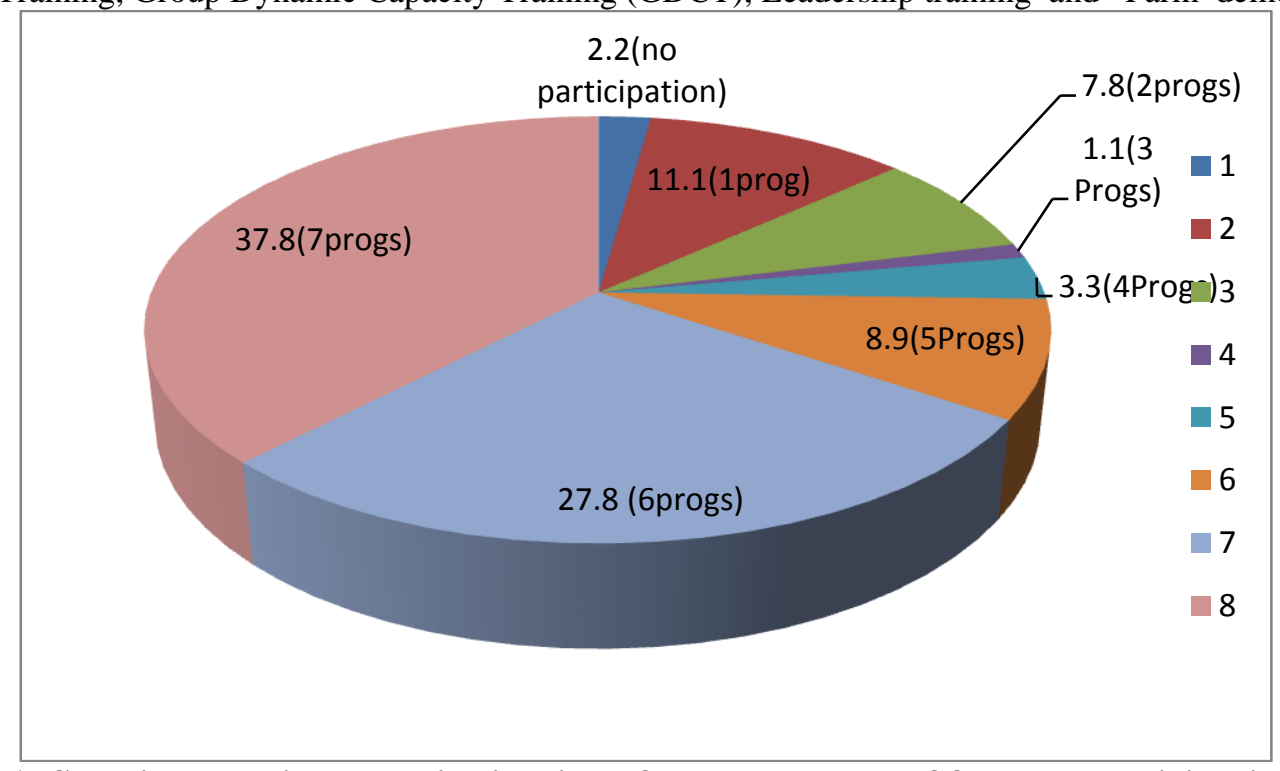

Figure 1: Showing the pie chart distribution of the percentage of farmers participation in the capacity building programme in Patigi Local Government

Note $:$ progs $=$ programmes 
Source: Field Survey, 2010

Figure 1 shows that in Patigi local government, 2.2\% did not participate in any of the capacity building programmes, $11.1 \%$ participated in only one programme, $7.8 \%$ participated in the two programmes only, $1.1 \%$ participated in three programme, $3.3 \%$ participated in four of the programmes, $8.9 \%$ participated in five of the programme, many (27.8\%) participated in six of the programmes, while majority $(37.8 \%)$ of the respondents in the Pategi local government involved themselves with all the seven programmes. The participation mean according to table 1 is 6.1889 , that mean on the average, out of seven programme, six programme were fully attended by the participant.

The implication of this is that the objective of the programme which is to impart to farmers rice production new technologies may not been fully realized because not all the capacity building programmes were fully attended.

Table 2: Regression analysis showing relationship between participation levels in Patigi LGA and some

\begin{tabular}{|c|c|c|c|c|c|c|}
\hline \multirow{9}{*}{1} & Variables & B & SE & STD Beta & T-ratio & Sig \\
\hline & (Constant) & -.722 & .253 & & -2.850 & .006 \\
\hline & Age & .010 & .006 & .062 & 1.802 & .075 \\
\hline & Educational levels & 1.673 & .150 & .762 & 11.123 & .000 \\
\hline & Household size & .262 & .226 & .094 & 1.156 & .251 \\
\hline & Farm size & -1.234 & .231 & -.424 & -5.348 & .000 \\
\hline & Ownership of land & -.158 & .098 & -.095 & -1.613 & .111 \\
\hline & Farming experience & .098 & .181 & .037 & .541 & .590 \\
\hline & $\begin{array}{l}\text { Secondary } \\
\text { occupation. }\end{array}$ & .920 & .196 & .479 & 4.690 & .000 \\
\hline
\end{tabular}

$\mathrm{R}=0.969, \mathrm{R} 2=0.940$, Adjusted R2 $=0.934, \mathrm{~F}=157.3$, Standard Error of Estimate $=0.57$.

Regression analysis (Table 2) shows that there were positive relationships between participation levels of farmers in capacity building programmes and age $(\beta=0.062)$, educational levels $(\beta=0.762)$, household size $(\beta=$ $0.037)$ years of experience in $(\beta=0.037)$, and secondary occupation $(\beta=0.479)$. The most significant variables among them were educational levels and secondary occupation of the respondents. The result implies that the increase in the farmers' age, the more they participated in the programme. This may be possible, but is contrary to expectation as participation expected to decrease with age, but because the mean age of the farmers that participated in the programme in Patigi Local Government is 40 years which mean they are still in their active stage of life and very close to youth ages category, that is the period of 15-35 years according to (Chigunta, [13]) . Likewise, the increase in education will lead to increase in the level of participation of farmers in the capacity building programme. This agree with finding of (Norsida and Sami, [14]) in which they find that educational level has a positive effect on participation. Moreover, the positive relationship between the household size and participation level is also in agreement with the finding of (Alarima et al [15]).

On the other hand, the regression coefficients between levels of participation and farm size (- 0.424) and land ownership. (-0.095). This implies that an increase in farm size lead to less participation in the capacity building training programme. This may be as a result of misplacement of priority, as some of them may be too busy to attend the training or they might see themselves not to need training since they are large scale producer. On the issue of land ownership, the more they lack control on the land the less they participate on capacity building programme. 


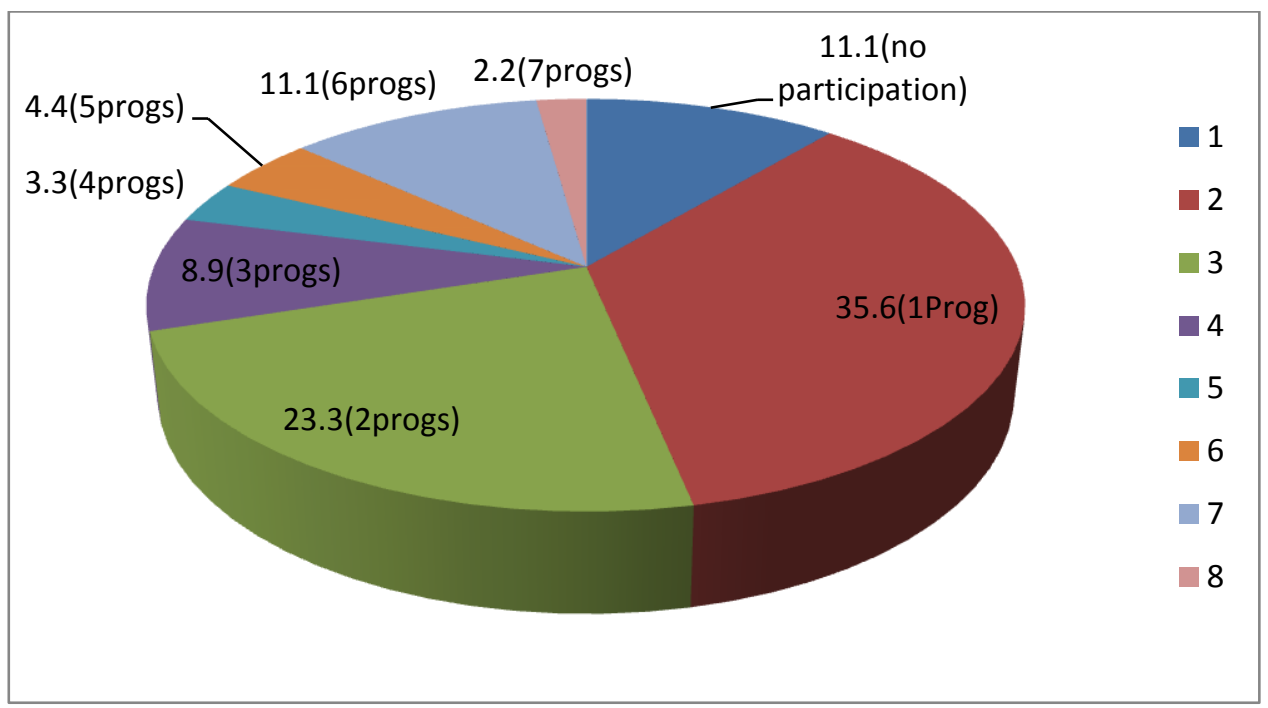

Figure 2: Showing the pie chart distribution of the percentage of farmers participation in the capacity building programme in Edu Local Government Source: Field Survey, 2010

Figure 2 shows that in Edu local government, $11.1 \%$ did not participate in any of the programme, the majority (35.6\%) participated in one of the programme, many (23.3\%) participated in the two of the programme, $8.9 \%$ participated in three programmes, $3.3 \%$ participated in four of the programmes, $4.4 \%$ participated in five of the programme, $11.1 \%$ participated in six of the programmes while only $2.2 \%$ participated in all the seven programme. The participation mean, according to table 1 is 3.2667 , that mean for the average, out of seven programmes, two programmes was fully attended by the participant.

The implication of this is that the objective of the programme which is capacity building for effective boost in rice production may not be fully realized because not all the capacity building programmes were fully attended by the participant.

Table 3: Regression analysis showing relationship between participation levels in Edu LGA and some selected study variables:

\begin{tabular}{|c|c|c|c|c|c|}
\hline Variables & B & $\mathbf{S ~ E}$ & STD Beta & T-ratio & Sig \\
\hline (Constant) & -.865 & .220 & & -3.928 & .000 \\
\hline Age & .003 & .004 & .014 & .662 & .510 \\
\hline Educational level & .218 & .099 & .114 & 2.208 & .030 \\
\hline Household size & .148 & .143 & .061 & 1.034 & .304 \\
\hline Farm size & .337 & .156 & .133 & 2.157 & .034 \\
\hline Ownership & .745 & .065 & .514 & 11.531 & .000 \\
\hline Farm experience & .263 & .121 & .114 & 2.169 & .033 \\
\hline $\begin{array}{l}\text { Secondary } \\
\text {.occupation }\end{array}$ & .234 & .132 & .140 & 1.775 & .080 \\
\hline
\end{tabular}

$\mathrm{R}=0.982, \mathrm{R} 2=0.964$, Adjusted R2 $=0.961, \mathrm{~F}=314.3$, Standard Error of Estimate $=0.38$.

Regression analysis (Table 3) showed that there were positive relationships between participation levels of farmers in capacity building programmes and selected variables: age $(\beta=0.014)$, educational levels $(\beta=0.114)$, household size $(\beta=0.061)$, farm size $(0.133)$, land ownership $(0.514)$, years of experience in $(\beta=0.114)$ and secondary occupation $(\beta=.140)$.this implies that all the variables are in support of the participation positively but the most significant variables are educational levels of farmers, farm size and land ownership. This implies that an educational level of farmers is the most important factor of participation. 


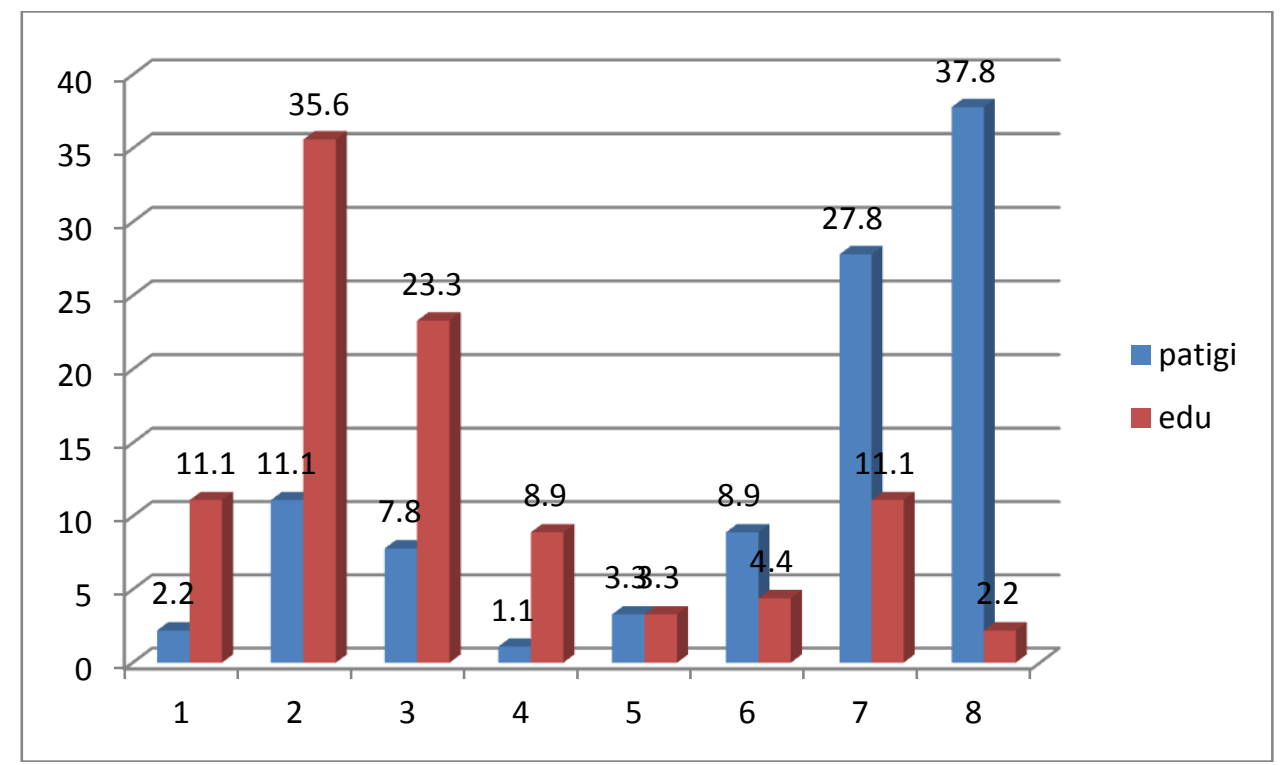

Figure 3: Showing the differences in the participation levels of the programmes between the Edu and Patigi Local Government Area.

Figure 3 Shows that the percentage of farmers that did not participate at all in all the seven capacity building programmes is higher $(11.1 \%)$ in Edu LGA than in Patigi (2.2\%). Those who participated in only one programme is higher (35.6\%) in Edu LGA than in Patigi (11.1\%). In the same vein, rice farmers' participation in only two of the programmes is higher $(23.3 \%)$ in Edu than patigi(7.8\%). Likewise, rice farmers' participation in only three of the programmes is higher (8.9\%) in Edu than patigi(1.1\%).

However, both Edu and Patigi have the same level of participation (3.3\%) in four of the capacity building programmes, but the reverse is the case when it comes to five programmes as the level of participation in Patigi is double (8.9\%) than that of Edu (4.4\%). Meanwhile, the participation in Patigi is more than double (27.8\%) that of Edu (11.1\%). On the contrary the participation level in Patigi is almost 20 times (37.8\%) that of Edu $(2.2 \%)$.

\section{Conclusion}

The assessment of the participation of rice farmers in a capacity building programme of Agricultural Development Programme in Kwara State has revealed that the participation level in Patigi Local Government Area is higher than that of the Edu local Government Area. The participation mean of farmers in Patigi is 6 . 1889 while that of Edu is 3.2667

Therefore, there is need to find out the reasons why the attendance was very low in the Edu Local Government Area while its considerable high in Patigi Local Government. However, the major reason given by the member of rice farmer participant is the mobility as the distance between their district and the programme venue is far.

The result revealed that for any subsequent training programme, the planner should take into consideration the educational levels, farm size, secondary occupation and land ownership of farmers into consideration as all these influence participation in one way or the other. Also, it was revealed that farmers' reason for inadequate participation was a result of distance of the venue where the programme is held.

\subsection{Recommendation}

Based on the findings of this study it is recommended that Agricultural Development Programme should decentralized their subsequent capacity building programme's venue so that farmers can have access to such programme. It is also recommended that for any subsequent training programme, the planner should take into consideration the educational levels, farm size, secondary occupation and land ownership of farmers into consideration as all these influence participation in one way or the other 


\section{References}

[1] Ajayi, A. O.Identification of Training Needs of Women Farmers in Oyo State. Unpublished M.Sc. thesis, Agricultural Extension and Rural Sociology, O. A. U, Ile-Ife. 1995.

[2] Owona, N. P. A., Nyaka, N. A., Ehabe, E. E., Chambon-Poveda, B. and Bruneau, J. C., Assessment of training needs of rubber farmers in the south-west region of Cameroon. African Journal of Agricultural Research 5 (17) (2010). :2326-2331

[3] USAID Markets: improved package of practices for rice production by USAID market, , (2010) $30 \mathrm{pp}$.

[4] USAID Markets, improved package of practices for rice production by USAID market, (2010): $30 \mathrm{pp}$.

[5] Ibrahim, M., Farmers trained on modern rice production retrieved from http://agronigeria.com.ng/2013/12/18/farmers-trained-onmodern-rice-production/ on 18/2/14.,.,(2013)

[6] Fashola, O. O., Oladele, O. I., Aliyu, J. and Wakatsuki, T. Dissemination of sawah rice technology to farmers cultivating inland valleys in Nigeria. Proceedings of the Asian Pacific Extension Network, 6-8 $8^{\text {th }}$ March 2006, Australia.

[7] Mengistu, F. T. Problems and Prospects of Farmers Training Centers: The Case of Ada'a Woreda, East Shewa, Oromia Region. M.Sc. thesis Haramaya University. (2009).

[8] Bari, M. A. K.,Training and Education in Rural Development. Bids, Dhaka. . (1987).

[9] Isiaku,S Farmers trained on modern rice production retrieved from http://agronigeria.com.ng/2013/12/18/farmers-trained-onmodern-rice-production/ on 18/2/14.(2013)

[10] Kwara State Agricultural Development Project (KWADP)(2007). Ilorin, Nigeria.

[11] The Met. Office ,Climatological Data for Agricultural Land Classification, Ilorin, Nigeria. (2007),

[12] NPC, National Population Commission Office, Ilorin, Nigeria. (1991).

[13] Chigunta, F. Youth Entrepreneurship: Meeting the Key Policy Challenges. Final paper retrieved http://yesweb.org/gkr/res/bg.entrep.ta.doc (2002). 232/14,

[14] Norsida, M. and Sadiya,. S.I. Off-farm employment participation among paddy farmers in the muda agricultural development authority and Kemasin Semerak Granary areas of Malaysia Asia-pacific Development Journal 16, (2), December 2009.

[15] Alarima, C. I., Kolawole, A., Fabusoro, E, Ajulo A. A., Masunaga . T. and Wakatsuki T.(2011) Knowledge and training needs of farmers adopting sawah rice production technology in Nigeria Journal of Food, Agriculture \& Environment, 9 (3\&4), JulyOctober 2011.pp 183-188. Retrieved from http://world-food.net/download/journals/2011-issue 3 4/003\%282\%29.pdf on 15/2/2014 